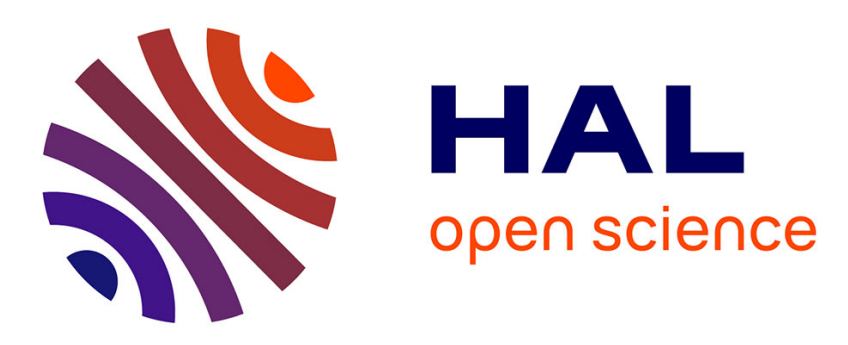

\title{
Synthesis and characterization of rare-earth orthoferrite LnFeO3 nanoparticles bioimaging
}

Sonia Pinho, João Amaral, Alain Wattiaux, Mathieu Duttine, Marie-Hélène Delville, Carlos F. G. C. Geraldes

\section{- To cite this version:}

Sonia Pinho, João Amaral, Alain Wattiaux, Mathieu Duttine, Marie-Hélène Delville, et al.. Synthesis and characterization of rare-earth orthoferrite LnFeO3 nanoparticles bioimaging. European Journal of Inorganic Chemistry, 2018, 2018 (31), pp.3570-3578. 10.1002/ejic.201800468 · hal-01864259

\section{HAL Id: hal-01864259 \\ https://hal.science/hal-01864259}

Submitted on 29 Jan 2021

HAL is a multi-disciplinary open access archive for the deposit and dissemination of scientific research documents, whether they are published or not. The documents may come from teaching and research institutions in France or abroad, or from public or private research centers.
L'archive ouverte pluridisciplinaire HAL, est destinée au dépôt et à la diffusion de documents scientifiques de niveau recherche, publiés ou non, émanant des établissements d'enseignement et de recherche français ou étrangers, des laboratoires publics ou privés. 


\title{
Synthesis and characterization of rare earth orthoferrite $\mathrm{LnFeO}_{3}$ nanoparticles for bioimaging
}

\author{
Sonia L.C. Pinho, ${ }^{[a, b, c]}$ João S. Amaral, ${ }^{[d]}$ Alain Wattiaux,${ }^{[b]}$ Mathieu Duttine,${ }^{[b]}$ Marie-Hélène Delville, ${ }^{[b]^{*}}$ \\ and Carlos F.G.C. Geraldes ${ }^{[\mathrm{e}, \mathrm{f}]^{*}}$
}

Dedication ((optional))

\begin{abstract}
A combination of sol-gel synthesis and thermal decomposition was developed for preparing nano-sized, perovskitetype $\mathrm{LnFeO}_{3}(\mathrm{Ln}=\mathrm{Eu}, \mathrm{Gd}, \mathrm{Tb})$ powders. Perovskite-type powders with crystalline particles of $100 \mathrm{~nm}$ average size, as determined by transmission electron microscopy (TEM), could be obtained after a thermal treatment at $800{ }^{\circ} \mathrm{C}$. The perovskite nanoparticles (NPs) were further characterized by X-ray powder diffraction and Mössbauer spectroscopy. These were in agreement with the pure perovskite $\mathrm{LnFeO}_{3}$ structure with the expected Zeeman sextet corresponding to a magnetically ordered phase. Magnetization measurements $(\mathrm{M}(\mathrm{H}))$ at $5 \mathrm{~K}$ and $300 \mathrm{~K}$ showed a behavior that is dominated by antiferromagnetic interactions and weak ferromagnetism in $\mathrm{EuFeO}_{3}$, while for $\mathrm{Ln}=\mathrm{Gd}$, Tb they were dominated by the low ordering temperature Ln magnetic sublattice. The colloidal aqueous NPs suspensions exhibited no significant leaching of free $\mathrm{Ln}^{3+}$ ions. Their relaxivities define them as potential $\mathrm{T}_{2} \mathrm{MRI}$ contrast agents for further biomedical applications. The NPs showed fast uptake and no cytotoxicity at concentrations below 62.5 $\mu \mathrm{g} / \mathrm{mL}$ with respect to Hela cells.
\end{abstract}

\section{Introduction}

Magnetic resonance imaging (MRI) has emerged as one of the most powerful clinical imaging tools due to its superb spatial resolution and excellent soft tissue contrast, which mostly results

[a] Dr S. L.C. Pinho,

Department of Chemistry, CICECO, University of Aveiro, 3810-193 Aveiro, Portugal

[b] Drs S. L.C. Pinho, A. Wattiaux, M. Duttine, M.-H. Delville CNRS, Univ. Bordeaux, ICMCB, UMR 5026

F-33600 Pessac, France

E-mail: marie-helene.delville@icmcb.cnrs.fr

[c] Dr S. L.C. Pinho

present address: Biocant - Biotechnology Innovation Center,

Parque Tecnológico de Cantanhede, Núcleo 4, Lote 8,

3060-197 Cantanhede, Portugal

[d] Dr João S. Amaral

Department of Physics, CICECO

University of Aveiro, 3810-193 Aveiro, Portugal

[e] Pr.Carlos F.G.C. Geraldes

Department of Life Sciences, Faculty of Science and Technology,

Calçada Martim de Freitas, University of Coimbra,

3000-393 Coimbra, Portugal

E-mail: geraldes@ci.uc.pt

[f] Pr.Carlos F.G.C. Geraldes

Coimbra Chemistry Center, Rua Larga, University of Coimbra, 3004535 Coimbra, Portugal from intrinsic differences in the relaxation times $\left(T_{1,2}\right)$ of tissue water protons. The contrast between normal and diseased tissues can be dramatically improved by the use of contrast agents (CAs), namely paramagnetic $\mathrm{Gd}^{3+}$-based chelates, e.g. Gd-DTPA or superparamagnetic iron-oxide based nanoparticles ( $T_{1}$ - and $T_{2}$-shortening agents, respectively). ${ }^{[1-3]}$ There is a strong interest in developing novel nanoparticle based CAs with enhanced $T_{1}$ and/or $T_{2}$ relaxation properties. ${ }^{[4-9]}$ It was recently shown that gadolinium oxide $\left(\mathrm{Gd}_{2} \mathrm{O}_{3}\right)$ nanoparticles (NPs) can act as $T_{1} \mathrm{CAs}$, enhancing MRI signal intensity, due to the availability of $\mathrm{Gd}^{3+}$ ions at their surface to interact with water, ${ }^{[10}$ ${ }^{11]}$ in particular for very small $(5-10 \mathrm{~nm})$ nanocrystals. ${ }^{[12-14]}$

NPs with multimodal contrast imaging capabilities can offer synergistic advantages over those active for only a single modality. ${ }^{[15-18]}$ Several $T_{1}-T_{2}$ bimodal CAs for MRI have been developed ${ }^{[19]}$ mostly integrating a superparamagnetic iron oxide (magnetite or maghemite) core in a $\mathrm{Gd}^{3+}$-containing paramagnetic shell. ${ }^{[20-22]}$ However, in this arrangement, the strong magnetic field from the superparamagnetic core opposes the magnetic field created by the paramagnetic shell, decreasing its $T_{1}$ relaxation effect. ${ }^{[22]}$ If the paramagnetic material is located inside the superparamagnetic iron oxide, their magnetic fields reinforce each other, enhancing the $T_{1}$ contrast. Such a synergistic $T_{1}-T_{2}$ relaxation effect has been reported using $\mathrm{Gd}_{2} \mathrm{O}_{3}$ ultra-small clusters embedded in iron oxide nanoparticles. ${ }^{[23]}$

An alternative to generate $T_{1}-T_{2}$ relaxation effects is to use rareearth orthoferrite NPs. High-quality nanocrystalline rare-earth orthoferrites $\mathrm{LnFeO}_{3}(\mathrm{Ln}=$ rare earth) with a perovskite structure have been thoroughly studied since the 1960s because of their unique physical and chemical properties for various applications such as catalysts, ${ }^{[24,25]}$ gas separators, ${ }^{[26]}$ sensors ${ }^{[27]}$ and optomagnetic materials. ${ }^{[28-35]}$ The synthesis of the specific $\mathrm{LnFeO}_{3}$ phases is very challenging, since undesired phases can co-exist. An example is the garnet phase $\left(\mathrm{Ln}_{3} \mathrm{Fe}_{5} \mathrm{O}_{12}\right)$ with a thermodynamically more stable phase when compared to $\mathrm{LnFeO}_{3}{ }^{[32]}$ As the ionic radius of the $\mathrm{Ln}^{3+}$ decreases, the tolerance factor, $t$, defined by Goldschmidt, ${ }^{[31,36]}$ becomes smaller than the ideal value in the 0.9-1.0 range. This indicates that the perovskite structure distortion increases and becomes less stable due the increasing $\mathrm{Fe}^{3+}$ to $\mathrm{Ln}^{3+}$ ionic radius quotient, as the $\mathrm{Ln}^{3+}$ ions become too small to fit ideally into their eight coordination interstitial sites provided by the $\mathrm{O}^{2-}$ ions. ${ }^{[37,38]}$ Therefore, the synthesis of $\mathrm{LnFeO}_{3}$ perovskites becomes progressively more difficult with decreasing the ionic radius of the $\mathrm{Ln}$ element. ${ }^{[39,40]}$ The preparation of $\mathrm{LnFeO}_{3}$ has been achieved by many methods, including sol-gel, ${ }^{[41-44]}$ sonochemical, ${ }^{[31]}$ microwave-assisted, ${ }^{[45]}$ combustion synthesis, ${ }^{[30,46-50]}$ hetero-bimetallic precursor methods, ${ }^{[32]}$ and solvothermal ${ }^{[51]}$ and hydrothermal synthesis. ${ }^{\left[{ }^{[2]}\right.}$ 
In this work, we report a sol-gel / auto-combustion method / approach to prepare monophasic nanosized $\mathrm{LnFeO}_{3}(\mathrm{Ln}=\mathrm{Eu}$, $\mathrm{Tb}$ and $\mathrm{Gd}$ ) powders. The nanomaterials were characterized by transmission electron microscopy (TEM), X-ray powder diffraction (XRD), magnetization measurements and Mössbauer spectroscopy. The stability of aqueous suspensions of the $\mathrm{LnFeO}_{3}$ nanoparticles (NPs) was also studied by zeta potential and $\mathrm{Ln}^{3+}$ leaching measurements. The water proton relaxation effects of the $\mathrm{LnFeO}_{3}$ nanoparticles were also studied, in order to assess their utility as CAs for MRI. Finally, the cell internalization and cytotoxicity of the nanoparticles in Hela cells was investigated.

\section{Results and Discussion}

\section{Synthesis and Characterization of the Nanoparticles}

Aqueous suspensions of $\mathrm{LnFeO}_{3} \mathrm{NPs}$ were synthesized by solgel/auto-combustion, as described in the experimental section. The TEM images for $\mathrm{LnFeO}_{3}$ reveal spherical, particles with an average size $D_{\text {TEM }}$ of $100 \pm 30 \mathrm{~nm}$ (Table 1), as illustrated in the case of $\mathrm{GdFeO}_{3}$ in Figure 1.

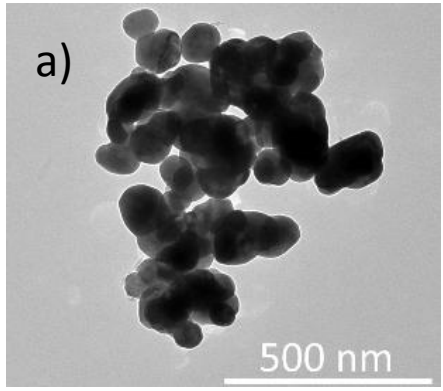

b)

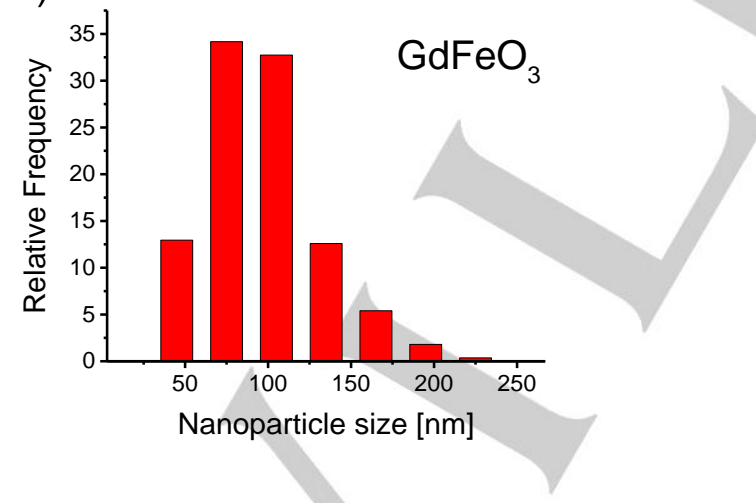

Figure 1. a) TEM image of the $\mathrm{GdFeO}_{3} \mathrm{NPs}$; b) histogram depicting the $\mathrm{GdFeO}_{3} \mathrm{NPs}$ size distribution. Size distributions for $\mathrm{EuFeO}_{3}$ and $\mathrm{TbFeO}_{3}$ are given in $\mathrm{SI}$ (Figure $\mathrm{S} 1$ ).

The elemental analyses of the different $\mathrm{LnFeO}_{3} \mathrm{NPs}$ (Table 1) show that the $\mathrm{Ln} / \mathrm{Fe}$ concentration ratios are very close but not equal to 1.0 , as expected, significant of the presence of a small amount of a second phase which was however difficult to identify due to its lack of crystallinity as shown later on.
Table 1. Elemental composition of samples $\mathrm{LnFeO}_{3}(\mathrm{Ln}=\mathrm{Eu}, \mathrm{Gd}$ and $\mathrm{Tb})$ ascertained by ICP-OES and NPs size by TEM (nm)

\begin{tabular}{ccc}
\hline $\mathrm{Ln}$ & $[\mathrm{Ln}] / \mathrm{Fe}]$ & TEM $(\mathrm{nm})$ \\
\hline $\mathrm{Eu}$ & $0.98(1)$ & $107 \pm 30$ \\
$\mathrm{Gd}$ & $0.98(1)$ & $96 \pm 31$ \\
\hline $\mathrm{Tb}$ & $0.92(1)$ & $115 \pm 31$ \\
\hline
\end{tabular}

Figures 2 to 4 show the X-ray diffraction profiles for the different compounds, which exhibit the typical Bragg reflections of the rare earth orthoferrites, indicating that the nanomaterials present a perovskite structure (space group $\mathrm{Pbnm}$ ) and are crystalline. ${ }^{[37}$, 38] The peak present at $\sim 27^{\circ}$ in the diffraction data of $\mathrm{EuFeO}_{3}$ comes from the graphite sample holder. The diffractograms were fitted using the Le Bail method, considering a single phase of orthoferrite with a perovskite structure and the red line represents the model obtained with this refinement; the dashed green line being the difference between the experimental data and the fit.

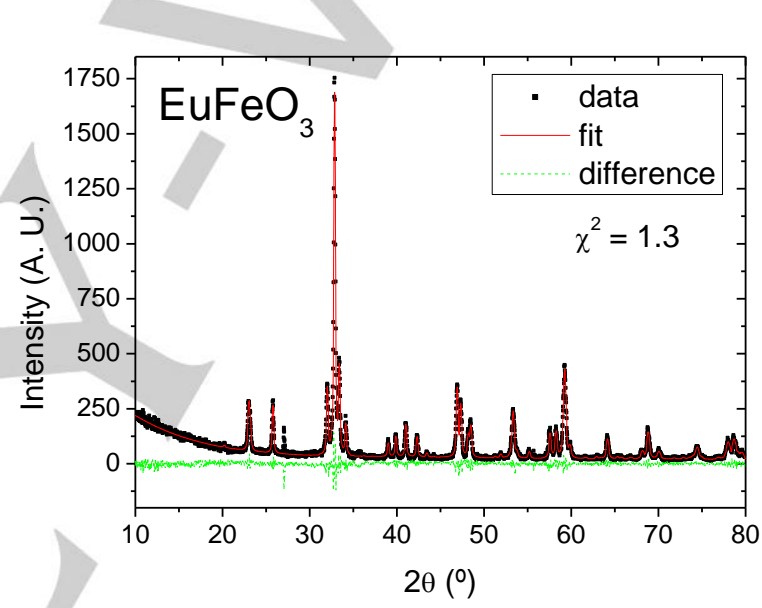

Figure 2. (Color online) X-Ray diffraction data of $\mathrm{EuFeO}_{3}$ (solid points), best fit (red line) and data to fit difference (dashed green line).

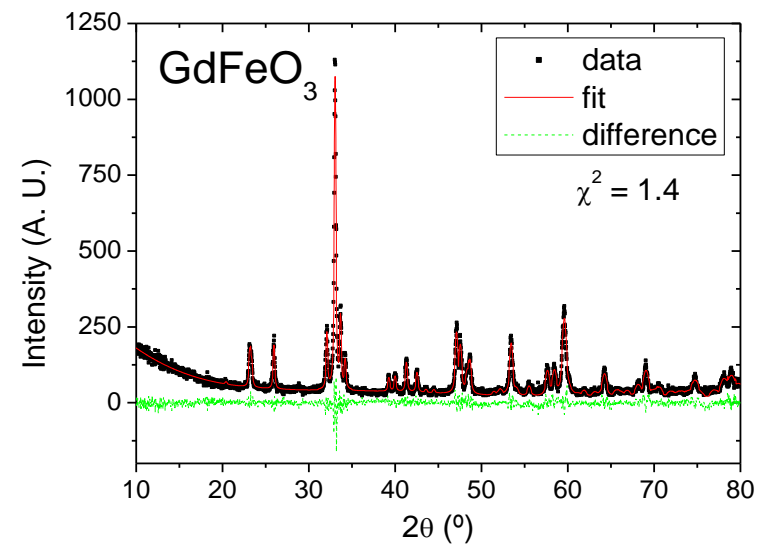

Figure 3. ((Color online) X-Ray diffraction data of $\mathrm{GdFeO}_{3}$ (solid points), best fit (red line) and data to fit difference (dashed green line). JCPDS 47-0067 


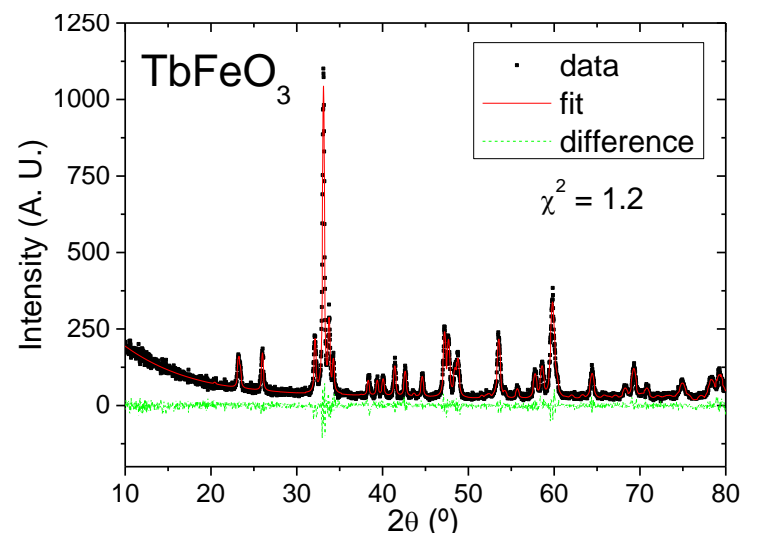

Figure 4. (Color online) X-Ray diffraction data of $\mathrm{TbFeO}_{3}$ (solid points), best fit (red line) and data to fit difference (dashed green line).

Table 2 shows the resulting lattice parameters and goodness of fit values for the studied $\mathrm{LnFeO}_{3}$ samples. They are in good agreement with those reported in bulk samples ${ }^{[53]}$ and recent work on micrometer-sized rare-earth orthoferrite particles ${ }^{[54]}$ or NPs. ${ }^{[43]}$ The $\mathrm{LnFeO}_{3}$ structure has a considerably distorted perovskite geometry, because $\mathrm{Ln}^{3+}\left(\mathrm{Gd}^{3+}, \mathrm{Eu}^{3+}\right.$, or $\left.\mathrm{Tb}^{3+}\right)$ has a coordination number of 8 , whereas the A-site in the ideal perovskite has a coordination number of 12 . This is due to the less favorable $\mathrm{Fe}^{3+}$ to $\mathrm{Ln}^{3+}$ ionic radius quotient with $\mathrm{r}\left(\mathrm{Fe}^{3+}\right) / \mathrm{r}$ $\left(\mathrm{Eu}^{3+}\right) \approx 0.605, \mathrm{r}\left(\mathrm{Fe}^{3+}\right) / \mathrm{r}\left(\mathrm{Gd}^{3+}\right) \approx 0.612$ and $\mathrm{r}\left(\mathrm{Fe}^{3+}\right) / \mathrm{r}\left(\mathrm{Tb}^{3+}\right) \approx$ $0.620,{ }^{[55]}$ as opposed to the 0.56 value for a typical cubic perovskite such as in $\mathrm{SrTiO}_{3}$. In none of these diffraction patterns, we were able to identify any of the usually encountered phases beside $\mathrm{LnFeO}_{3}$.

Table 2. Lattice parameters and of the studied $\mathrm{LnFeO}_{3}$ samples.

\begin{tabular}{llllll}
\hline Compound & $a(n m)$ & $b(n m)$ & $c(n m)$ & $v\left(n n^{3}\right)$ & $\chi^{2}$ \\
$\mathrm{EuFeO}_{3}$ & 0.5369 & 0.5593 & 0.7683 & 0.2307 & 1.3 \\
$\mathrm{GdFeO}_{3}$ & 0.5350 & 0.5607 & 0.7669 & 0.2301 & 1.4 \\
$\mathrm{TbFeO}_{3}$ & 0.5328 & 0.5593 & 0.7645 & 0.2278 & 1.2 \\
\hline
\end{tabular}

\section{Mössbauer spectroscopy}

Mössbauer room temperature experimental spectra of $\mathrm{LnFeO}_{3}$ tare illustrated in Figure 5 with their calculated spectra, while the hyperfine parameters are gathered in Table 3 . For the three compounds, the major contribution is described by the presence of a magnetically ordered sextet. ${ }^{[56-67]}$ The refined values of the hyperfine parameters are consistent with high-spin iron(III) ions located at a crystallographic site in octahedral symmetry (site 1) in good agreement with the perovskite structure of these compounds. The isomer shift $(\delta)$ values determined for the $\mathrm{EuFeO}_{3}$ and $\mathrm{TbFeO}_{3}$ samples are very close to those reported in previous studies for similar compounds. ${ }^{[56,57,61,66-68]}$ The values of the hyperfine field are around $50 \mathrm{~T}$, indicating that the hyperfine field is very close to the saturated field. These results are in good agreement with the XRD crystallographic studies. $\mathrm{GdFeO}_{3}$ is the only one to be pure within the limit of detection of the technique while the two other compounds, $\mathrm{EuFeO}_{3}$ and $\mathrm{TbFeO}_{3}$, both exhibit an additional signal, which is not magnetically ordered at room temperature. This minor component (about $3 \%$ in relative area), described by a quadrupole doublet with an isomer shift $\delta \approx 0.15-0.20 \mathrm{~mm} / \mathrm{s}$ and a quadrupole splitting $\Delta \approx 0.4-0.5 \mathrm{~mm} / \mathrm{s}$, was not detected on the respective $\mathrm{XRD}$ patterns. It could be associated with an unidentified iron-containing impurity as suggested by the results of ICP elemental analyses.

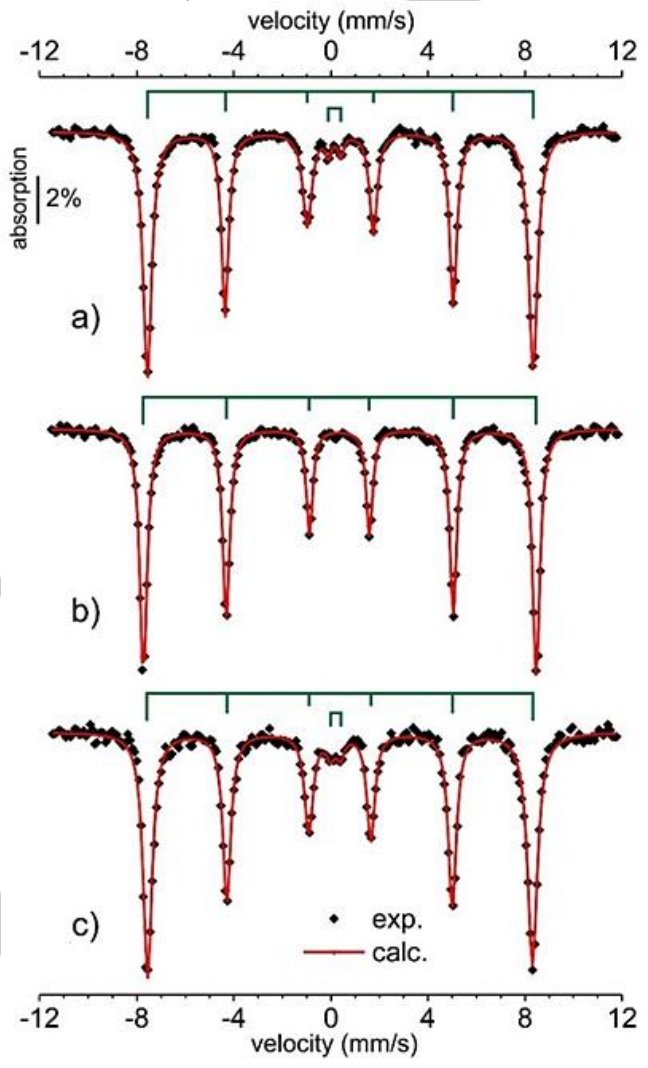

Figure 5. ${ }^{57} \mathrm{Fe}$ room temperature Mössbauer spectra of (a) $\mathrm{EuFeO}_{3}$, (b) $\mathrm{GdFeO}_{3}$ and (c) $\mathrm{TbFeO}_{3}$. The refined hyperfine parameters associated with the magnetic sextets and paramagnetic quadrupole doublets are reported in Table 3.

Table 3. Refined hyperfine parameters estimated from the analysis of the ${ }^{57} \mathrm{Fe}$ Mössbauer spectra presented in Figure 5 . $\delta$ : isomer shift (relative to $\alpha-\mathrm{Fe}$ ) at room temperature, $\Delta$ : quadrupole splitting, $\varepsilon$ : quadrupole shift, $\mathrm{H}$ : hyperfine magnetic field, $\Gamma$ : Lorentzian linewidth.

\begin{tabular}{|c|c|c|c|c|c|c|}
\hline Compound & $\begin{array}{l}\delta \\
(\mathrm{mm} / \mathrm{s})\end{array}$ & $\begin{array}{l}\Delta \\
(\mathrm{mm} / \mathrm{s})\end{array}$ & $\begin{array}{l}2 \varepsilon \\
(\mathrm{mm} / \mathrm{s})\end{array}$ & $\begin{array}{l}\mathrm{H} \\
(\mathrm{T})\end{array}$ & $\begin{array}{l}\Gamma \\
(\mathrm{mm} / \mathrm{s})\end{array}$ & $\begin{array}{l}\text { area } \\
(\%)\end{array}$ \\
\hline $\mathrm{EuFeO}_{3}$ & & & & & & \\
\hline $\begin{array}{r}\text { sextet } \\
\text { doublet }\end{array}$ & $\begin{array}{c}0.376(4) \\
0.15(2)\end{array}$ & $\begin{array}{c}- \\
0.51(2)\end{array}$ & $\begin{array}{c}0.046(5) \\
-\end{array}$ & $\begin{array}{c}50.1(5) \\
-\end{array}$ & $\begin{array}{l}0.44(5) \\
0.27(3)\end{array}$ & $\begin{array}{c}97(1) \\
3(1)\end{array}$ \\
\hline $\mathrm{GdFeO}_{3}$ & & & & & & \\
\hline $\begin{array}{l}\text { sextet } \\
\mathrm{TbFeO}_{3}\end{array}$ & $0.363(4)$ & - & $0.002(5)$ & $50.0(5)$ & $0.34(3)$ & 100 \\
\hline sextet & $0.370(4)$ & - & $0.021(5)$ & $49.5(5)$ & $0.44(5)$ & $97(1)$ \\
\hline doublet & $0.19(2)$ & $0.37(2)$ & - & - & $0.37(3)$ & $3(1)$ \\
\hline
\end{tabular}

Moreover, the high values of the Lorentzian linewidth $(\Gamma)$ may reflect some local disorders in the iron environment (cationic heterogeneous distribution, site distortion) that could be related to the particle size and size dispersity (see Figure 1 and Table 1).

\section{Magnetization studies}

The magnetization of the $\mathrm{LnFeO}_{3} \mathrm{NPs}$ was studied as a function of the applied magnetic field. Their magnetic behavior results 
from the contribution of two magnetic sub-lattices: an antiferromagnetic iron oxide lattice with the spins coupled via a $\mathrm{Fe}^{3+}-\mathrm{O}^{2-}-\mathrm{Fe}^{3+}$ super exchange mechanism, and a paramagnetic contribution from non-coupled $\mathrm{Ln}^{3+}$ ions. Figure 6A shows the magnetization dependence of the $\mathrm{EuFeO}_{3}$ sample on applied magnetic field, at $5 \mathrm{~K}$. In accordance with reports of small spin canting phenomena in the Fe-containing sub-lattice, resulting from the distorted perovskite structures, which induce weak ferromagnetism in this system, ${ }^{[31,69,70]}$ we observe a small hysteresis with a coercive field of about $330 \mathrm{Oe}$, together with typical mainly antiferromagnetic behavior of the Fe sub-lattice.
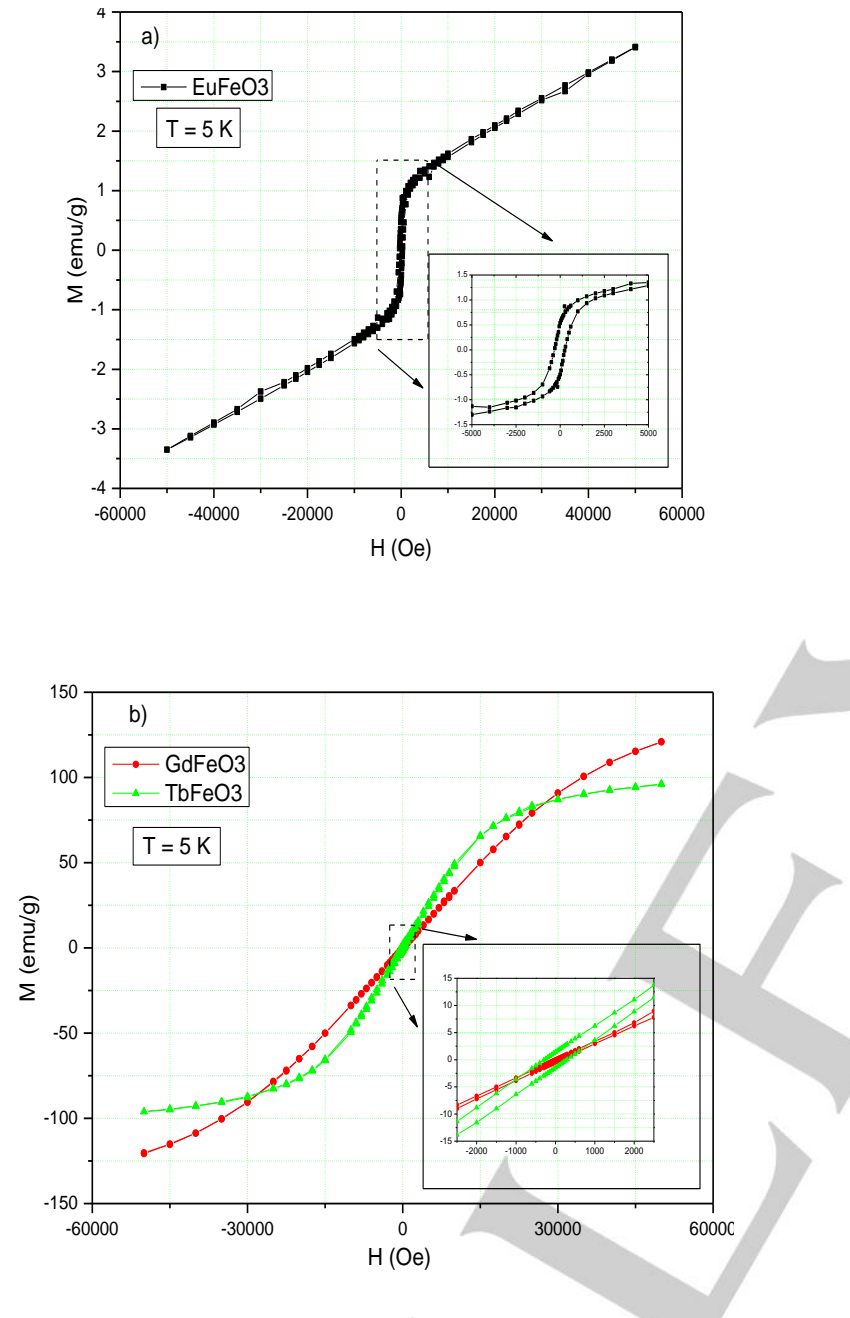

Figure 6. Magnetization versus applied magnetic field at $5 \mathrm{~K}$ a) for the $\mathrm{EuFeO}_{3}$ sample; b) for the $\mathrm{LnFeO}_{3}(\mathrm{Ln}=\mathrm{Gd}$, Tb) samples. Inset shows detail at low field.

Figure $6 \mathrm{~b}$ shows the magnetization versus field dependence at 5 $\mathrm{K}$ for the $\mathrm{GdFeO}_{3}$ and $\mathrm{TbFeO}_{3}$ samples. The much higher values of magnetization $\left(\mathrm{MS}_{\mathrm{S}}\right)$ as compared to the $\mathrm{EuFeO}_{3}$ sample show that the magnetization versus applied field behavior at this temperature is dominated by the rare-earth ions. In the case of $\mathrm{TbFeO}_{3}$, the rare-earth sub-lattice is magnetically ordered below $8.4 \mathrm{~K}$, justifying the observed approach to saturation at $5 \mathrm{~K} \cdot{ }^{[71-73]}$ Comparatively, the ordering temperature for the $\mathrm{Gd}$ sub-lattice in $\mathrm{GdFeO}_{3}$ is $2.5 \mathrm{~K},{ }^{[74]}$ and the behavior is paramagnetic. The magnetization curve for $\mathrm{GdFeO}_{3}$ at $5 \mathrm{~K}$ is significantly different from that reported for much smaller (3.5-5.0 nm) $\mathrm{GdFeO}_{3} \mathrm{NPs}$ at $2 \mathrm{~K}$, with a saturation magnetization $\mathrm{M}_{\mathrm{S}}=80$ emu. $\mathrm{g}^{-1}$. $^{[43]}$
At $300 \mathrm{~K}$, for all the $\mathrm{LnFeO}_{3}$ systems studied, there is no sign of saturation even at $50 \mathrm{KOe}(5 \mathrm{~T})$. In the case of $\mathrm{EuFeO}_{3}$, where the magnetization comes only from the $\mathrm{Fe}$ sub-lattice, a maximum value of $\sim 2.5 \mathrm{emu} / \mathrm{g}$ is observed, as shown in Figure 7 . For $\mathrm{GdFeO}_{3}$ and $\mathrm{TbFeO}_{3}$, these values are $\sim 6 \mathrm{emu} / \mathrm{g}$ and $\sim 9$ $\mathrm{emu} / \mathrm{g}$ respectively. Assuming that in these two compounds the magnetic contribution of the $\mathrm{Fe}$ sublattice is similar to that observed in $\mathrm{EuFeO}_{3}$ at this temperature and applied field range, the magnetic $\mathrm{Gd} / \mathrm{Tb}$ ion contribution to the total magnetization is comparable to that of the Fe sub-lattice.

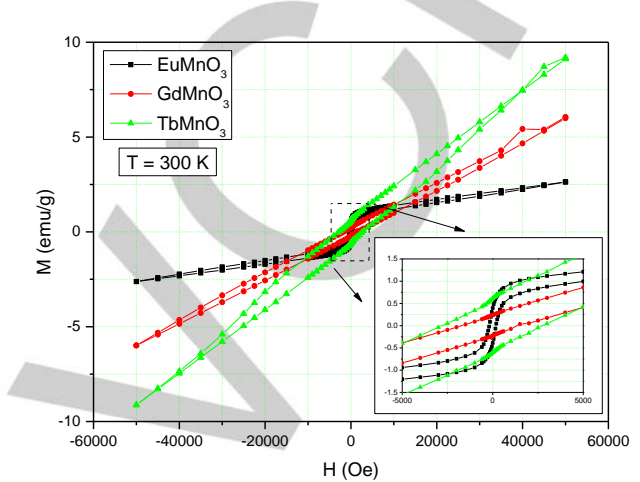

Figure 7. Magnetization versus applied magnetic field for the $\mathrm{LnFeO}_{3}(\mathrm{Ln}=\mathrm{Eu}$, $\mathrm{Gd}, \mathrm{Tb}$ ) samples, at $300 \mathrm{~K}$. Inset shows detail at low field.

There is nonetheless a magnetic interaction between the rareearth ions and the Fe lattice, as the coercive field and hysteresis width noticeably increase with the presence of a magnetic rareearth ion. The magnetization values at $300 \mathrm{~K}$ reported here are in agreement with previous reports on the properties of these rare-earth orthoferrite materials ${ }^{[50,75-77]}$ while coercive field values in the range of the hundreds of Oe are comparable to recent reports. ${ }^{[31,32]}$

\section{Solution studies}

The zeta potential titration as a function of $\mathrm{pH}$ confirmed the negative charge of the NPs over most of the $\mathrm{pH}$ range (Supplementary Information, Figure S2), with a point of zero charge close to 3 providing a colloidal stability in physiological conditions.

Due to the magnetic properties of the $\mathrm{LnFeO}_{3} \mathrm{NPs}$, they were tested as $T_{1}-T_{2} \mathrm{MRI}$ CAs. Table 4 shows the water ${ }^{1} \mathrm{H}$ relaxivity values $\left(r_{1}\right.$ and $\left.r_{2}\right)$ and the $r_{2} / r_{1}$ ratios, measured at $20 \mathrm{MHz}$ and $298 \mathrm{~K}$ and $310 \mathrm{~K}$, for clear suspensions of the $\mathrm{EuFeO}_{3}, \mathrm{TbFeO}_{3}$, and $\mathrm{GdFeO}_{3} \mathrm{NPs}$ in water and compares them with literature data. ${ }^{[43]}$ The relaxivities were obtained from the observed linear dependence of the $R_{\mathrm{i}}\left(R_{\mathrm{i}}=1 / T_{\mathrm{i}}, \mathrm{i}=1,2\right)$ relaxation rates on the concentration of the $\mathrm{Ln}^{3+}$ ions in the samples, using at least five independent measurements at concentrations between 0 and 2 $\mathrm{mM}$, as shown in SI Figures S3 and S4.

The observed $r_{1}$ values are quite low for all the studied samples, although slightly larger for $\mathrm{Ln}=\mathrm{Gd}$ and $\mathrm{Tb}$ than for Eu. The $\mathrm{r}$ and $r_{2}$ relaxivities can have contributions from inner-sphere (IS) and outer-sphere (OS) mechanisms. ${ }^{[1,5,78]}$ The IS mechanism results from the water molecules directly coordinated to the $\mathrm{Ln}^{3+}$ ions on the surface of the NPs, which affects their proton relaxation through contact and dipolar terms (for $\mathrm{Gd}^{3+}$ ) and also a Curie term (for the other paramagnetic $\mathrm{Ln}^{3+}$ ). It depends on the 
longitudinal relaxivity of the inner-sphere water molecules directly coordinated to the surface $\mathrm{Ln}^{3+}$ ions, their hydration number, and the surface-to-volume $(\mathrm{S} / \mathrm{V})$ ratio of the NPs. ${ }^{[78,79]}$ The OS mechanism results from the diffusion of the water molecules in the magnetic field inhomogeneities created by the magnetized NPs in their vicinity, and does not contain the contact term. It depends on their distance of closest approach to the NPs surface, as well as on the NPs size and magnetization. ${ }^{[5}$ ${ }^{78]}$ The very small $r_{1}$ values observed for the $\mathrm{LnFeO}_{3} \mathrm{NPs}$ of 100 $\mathrm{nm}$ size (Table 4) are similar to those reported at low magnetic fields $(0.47-1.5 \mathrm{~T})$ for $\mathrm{Dy}_{2} \mathrm{O}_{3}{ }^{[79,80]}$ and $\mathrm{Gd}_{2} \mathrm{O}_{3}{ }^{[81-83]} \mathrm{NPs}$ of similar size $(20-100 \mathrm{~nm})$. There are however significant differences relatively to the $r_{1}$ data reported for analogous $\mathrm{GdFeO}_{3}$ nanomaterials (Table 4), ${ }^{[4]}$ which have larger $r_{1}$ values. This is attributed to the much smaller crystal size $(3.5-5.0 \mathrm{~nm})$ of these two samples. It is well-known that the $r_{1}$ values for NPs increase as their size decreases, as the number of paramagnetic metal ions at the surface increases with their $(\mathrm{S} / \mathrm{V})$ ratio. Depending on the magnetic field, the $r_{1}$ values of $\mathrm{Gd}_{2} \mathrm{O}_{3}$ NPs can go up to 12 $(1.5 \mathrm{~T})$ or $10 \mathrm{~s}^{-1} \mathrm{mM}^{-1}(3 \mathrm{~T})$ with optimal particle sizes of 1.6 and $3.8 \mathrm{~nm}$, respectively. ${ }^{[12,14,79,83-86]}$

The $r_{2}$ values observed for the $\mathrm{LnFeO}_{3} \quad \mathrm{NPS}$ (Table 4) are considerably higher than $r_{1}$, giving $r_{2} / r_{1}$ values much larger than 2 , which corresponds to a dominant $T_{2}$-weighted (negativecontrast) mechanism. The relative $r_{2}$ values at $298 \mathrm{~K}$ increase in the order $\mathrm{Gd}<\mathrm{Eu}<\mathrm{Tb}$, which partially disagrees with the relative magnetization values $(\mathrm{Gd}<\mathrm{Tb}<\mathrm{Eu}$, Figure 7 ) observed at $0.47 \mathrm{~T}(4700 \mathrm{Oe})$, where, due to the observed hysteresis, the upfield $\mathrm{M}(\mathrm{H})$ traces were considered. The $\mathrm{r}_{2}$ value observed for $\mathrm{EuFeO}_{3}$, where the magnetization comes only from the $\mathrm{Fe}$ sublattice, are smaller than would be expected from the OS mechanism. ${ }^{[78]}$ The $r_{2}$ values previously reported for the much smaller $\mathrm{GdFeO}_{3} \mathrm{NPs}$ at $1.5 \mathrm{~T}$ are somewhat larger (Table 4$)^{[43]}$ as a result of the higher magnetic field $(1.5 \mathrm{~T})$ used in that study. These results can be compared with reported $r_{2}$ data for paramagnetic $\mathrm{Ln}_{2} \mathrm{O}_{3}$ NPs in different experimental conditions. At the same magnetic field, the $r_{2}$ values of the paramagnetic $\mathrm{Ln}_{2} \mathrm{O}_{3}$ NPs of the same size have been found to increase with their magnetization, which is proportional to the square of the effective magnetic moment ( $\mu_{\text {eff }}$ ) of the $\mathrm{Ln}^{3+}$ ion (in the order $\mathrm{Eu}$ $<\mathrm{Gd}<\mathrm{Tb}) .{ }^{[78,81]}$ For the same $\mathrm{Ln}, \mathrm{r}_{2}$ was found to increase with the magnetic field $\mathrm{B}_{0}$ or with $\mathrm{B}_{0}{ }^{2} \cdot{ }^{[12,78,80,81]}$ The dependence of $r_{2}$ on the particle size is more complex, as found experimentally ${ }^{[12,}$ 14, 78-87] and predicted by the OS theory. ${ }^{[78,88-90]}$ For small particles, the Motional Averaging Regime (MAR) operates, and $r_{2}$ is proportional to $\left(\mu_{\text {eff }}\right)^{2} B_{0}^{2}$ and inversely proportional to the radius of the NP. For large particles, the Static Diffusion Regime (SDR) predicts that $r_{2}$ is proportional to $\left(\mu_{\text {eff }}\right)^{2} B_{0}$ and that it becomes dependent on the time interval between two consecutive $180^{\circ}$ pulses ( $T_{\mathrm{CP}}$ ) in the Carr-Purcell-Meiboom-Gill (CPMG) pulse sequence used to determine the $T_{2}$ values. This dependence is also influenced by the particle coating, as it may influence the distance of closest approach of the water molecules to the NPs surface.

Table 4. ${ }^{1} \mathrm{H}$ relaxivities, $r_{\text {ip }}(i=1,2)$, determined at $20 \mathrm{MHz}(0.47 \mathrm{~T})$, at $298 \mathrm{~K}$ and $310 \mathrm{~K}$, for aqueous suspensions of $\mathrm{EuFeO}_{3}, \mathrm{TbFeO}_{3}$, and $\mathrm{GdFeO}_{3}$, compared with values from the literature.

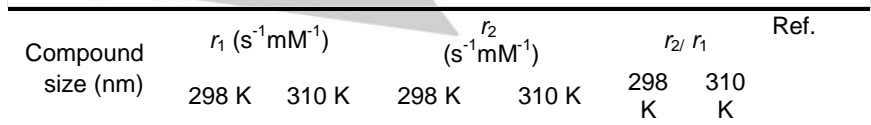

\begin{tabular}{|c|c|c|c|c|c|c|c|}
\hline $\begin{array}{c}\mathrm{EuFeO}_{3} \\
107 \pm 30\end{array}$ & $\begin{array}{c}0.20 \pm \\
0.01\end{array}$ & $\begin{array}{c}0.20 \pm \\
0.01\end{array}$ & $\begin{array}{c}6.18 \pm \\
0.06\end{array}$ & $\begin{array}{c}6.45 \pm \\
0.01\end{array}$ & 30.9 & 32.3 & $\begin{array}{l}\text { This } \\
\text { work }^{[a]}\end{array}$ \\
\hline $\begin{array}{c}\mathrm{TbFeO}_{3} \\
96 \pm 31\end{array}$ & $\begin{array}{l}0.68 \pm \\
0.05\end{array}$ & $\begin{array}{l}0.41 \pm \\
0.05\end{array}$ & $\begin{array}{c}9.45 \pm \\
0.02\end{array}$ & $\begin{array}{c}9.38 \pm \\
0.01\end{array}$ & 13.90 & 22.9 & $\begin{array}{l}\text { This } \\
\text { work }^{[\mathrm{a}]}\end{array}$ \\
\hline $\begin{array}{l}\mathrm{GdFeO}_{3} \\
115 \pm 31\end{array}$ & $\begin{array}{c}0.60 \pm \\
0.02\end{array}$ & $\begin{array}{l}0.59 \pm \\
0.07\end{array}$ & $\begin{array}{c}5.65 \pm \\
0.02\end{array}$ & $\begin{array}{c}3.84 \pm \\
0.01\end{array}$ & 9.42 & 6.52 & $\begin{array}{l}\text { This } \\
\text { work }^{[a]}\end{array}$ \\
\hline $\begin{array}{c}\mathrm{GdFeO}_{3} \\
\text { dialysed } 4 \mathrm{~h} \\
3.5\end{array}$ & 4.5 & & 11.3 & & & & {$[43]^{[b]}$} \\
\hline $\begin{array}{c}\mathrm{GdFeO}_{3} \\
\text { dialysed } 120 \mathrm{~h} \\
5\end{array}$ & 11.9 & & 15.2 & & 1.3 & & {$[43]^{[b]}$} \\
\hline Gd-DTPA & 4.1 & & 4.7 & & 1.1 & & {$[14]^{[c]}$} \\
\hline
\end{tabular}

[a] Measured at $0.47 \mathrm{~T}(20 \mathrm{MHz}) ;[\mathrm{b}]$ Measured at $1.5 \mathrm{~T}(64 \mathrm{MHz})$; [c] Measured at $1.5 \mathrm{~T}(64 \mathrm{MHz})$

Regarding the leaching of $\mathrm{Ln}^{3+}$ ions from the NPs, when we compare the concentration of free $\mathrm{Ln}^{3+}$ ions and the initial $\mathrm{Ln}$ within the NPs, no significant leaching of $\mathrm{Ln}^{3+}$ ions was observed in aqueous dispersions of the NPs stored at 4 oC for a week $\left(0.42 \%\right.$ for $\mathrm{Eu}^{3+}, 0.87 \%$ for $\mathrm{Tb}^{3+}$ and $1.4 \%$ for $\mathrm{Gd}^{3+}$, see Figure S5), as determined quantitatively using a spectrophotometric xylenol orange method. ${ }^{[91]}$ Values below $1.5 \%$ were obtained regarding leaching of $\mathrm{Ln}^{3+}$ ions form the NPs. This is an important condition to minimize their in vitro and in vivo toxicity.

\section{Cell internalization and cytotoxicity of NPs}

A preliminary assessment of the biological effect of the NPs on cell metabolism was evaluated after exposing Hela cells $\left(7 \times 10^{3}\right.$ cell/well) to increasing concentrations of NPs (from 7 to 250 $\mu \mathrm{g} / \mathrm{mL}$ ) for $24 \mathrm{~h}$. The uptake of NPs can cause changes in cell morphology, which can be observed after only a few hours of exposure to the NPs, suggesting interference with normal cell function. Reduction of ATP levels is considered a reliable cell viability marker. ${ }^{\left[{ }^{22}\right]}$ Cell metabolism was assessed by ATP production using a CellTiter-Glo ${ }^{\circledR}$ Cell Viability Assay. Figure 8 shows a decrease in ATP content of cells exposed for $24 \mathrm{~h}$ to higher concentrations of NPs. NPs concentrations equal or higher than $62.5 \mu \mathrm{g} / \mathrm{mL}$ showed extremely significant impaired ATP production relative to control $(P<0.0001$ or $P<0.01)$. Similar findings have been reported in a previous study for different sized $\mathrm{Fe}_{2} \mathrm{O}_{3}$ NPs. ${ }^{[93]}$ For concentrations below 62.5 $\mu \mathrm{g} / \mathrm{mL}$, the ATP production showed non-significant changes with respect to the controls for the three types of NPs, indicating no cytotoxicity of these NPs at concentrations below $62.5 \mu \mathrm{g} / \mathrm{mL}$ with respect to Hela cells. Further tests should be performed to assess in more detail the cytotoxicity of these particles in other cell lines. Nevertheless, the full viability of cells was ensured for the experimental concentration of $50 \mu \mathrm{g} / \mathrm{mL}$ used throughout our studies.

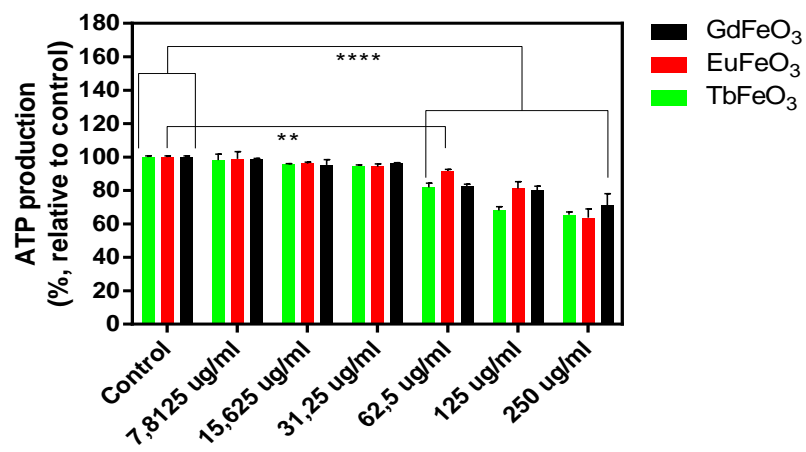


Figure 8. Effect of increasing concentrations of $\mathrm{NPs}\left(\mathrm{EuFeO}_{3}, \mathrm{TbFeO}_{3}\right.$ and $\mathrm{GdFeO}_{3}$ ) upon ATP production by Hela cells. Cells were incubated with the NPs for $4 \mathrm{~h}$, washed and left for $20 \mathrm{~h}$. The results are expressed as mean \pm $\mathrm{SD}(\mathrm{n}=3) .{ }^{* *}$ and ${ }^{* * * *}$ denote statistical significance $(\mathrm{P}<0.01$ and $\mathrm{P}<0.0001$, respectively)

The three systems $\left(\mathrm{EuFeO}_{3}, \mathrm{TbFeO}_{3}\right.$ and $\left.\mathrm{GdFeO}_{3}\right)$ were studied regarding their cell internalization and cytotoxicity. The internalization kinetics of the NPs in Hela cells was studied for three different incubation times: 2, 4 and $6 \mathrm{~h}$ and $50 \mu \mathrm{g} / \mathrm{mL}$ of NPs. To quantify the real amounts of NPs internalized in Hela cells at different times, inductively coupled plasma mass spectrometry (ICP-MS) was used (Figure 9). The results indicate a time-dependent increase in the uptake of the NPs by the cells. The internalization kinetics of the three types of NPs is quite similar, where a plateau $\left(\sim 2.0 \times 10^{5} \mathrm{NPs}\right.$ per cell), after $4 \mathrm{~h}$, is reached for the three systems and presents the same internalization efficiency with no statistical significance. Nevertheless, statistical difference between, the $\mathrm{GdFeO}_{3}$ and the $\mathrm{EuFeO}_{3}$ system, as for two different time points (4h and 6h) the $\mathrm{EuFeO}_{3}$ system showed less uptake.

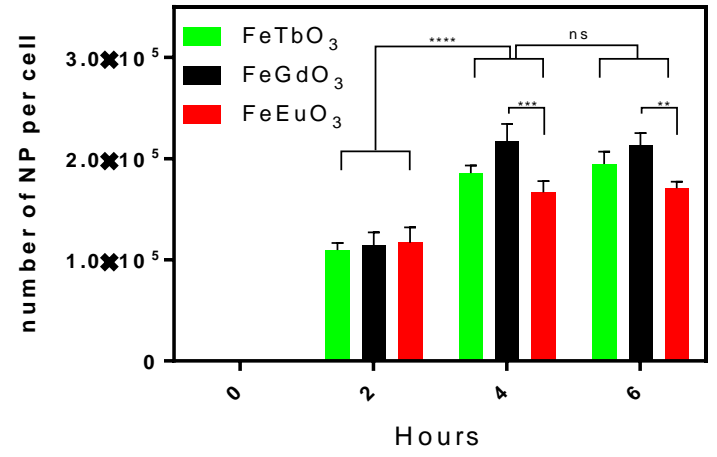

Figure 9. Quantification of NPs per Hela cells determined by ICP-MS analysis. Cells were incubated with $\mathrm{NPs}\left(\mathrm{EuFeO}_{3}, \mathrm{TbFeO}_{3}\right.$ and $\left.\mathrm{GdFeO}_{3}\right)$ for $2 \mathrm{~h}, 4 \mathrm{~h}$ and $6 \mathrm{~h}$. After the incubation, the cells were washed, trypsinized and finally freeze-dried. The number of NPs was determined by average NPs size and crystal unit method. The results are expressed as mean $\pm S D(n=3)$. **, *** and ${ }^{* * *}$ denote statistical significance $(P<0.01, P<0.001$, and $P<0.0001$, respectively).

\section{Conclusions}

It has been demonstrated that reproducible crystalline powders made of spherical, nanosized (100 $\pm 30 \mathrm{~nm}$ average diameter), perovskite-type $\mathrm{LnFeO}_{3}(\mathrm{Ln}=\mathrm{Eu}, \mathrm{Gd}$, Tb) particles can be synthesized by sol-gel auto-combustion after a thermal treatment at $800{ }^{\circ} \mathrm{C}$. Characterization by X-ray powder diffraction and Mössbauer spectroscopy confirmed a pure perovskite $\mathrm{LnFeO}_{3}$ structure for $\mathrm{GdFeO}_{3}$ whereas an additional $3 \%$ intensity quadrupole doublet was detected by Mössbauer in the case of $\mathrm{EuFeO}_{3}$ and $\mathrm{TbFeO}_{3}$. The field-dependent magnetization measurements at $5 \mathrm{~K}$ and $300 \mathrm{~K}$ revealed behaviour dominated by antiferromagnetic interactions and weak ferromagnetism of the Fe sub-lattice in the case of $\mathrm{EuFeO}_{3}$, while for $\mathrm{Ln}=\mathrm{Gd}$, Tb it becomes dominated by the contribution of the low ordering temperature Ln magnetic sub-lattice. The negatively charged colloidal aqueous NPs suspensions were stable and showed no significant leaching of free $\mathrm{Ln}^{3+}$ ions. These NPs exhibit very small $r_{1}$ relaxivities and larger $r_{2}$ values, which are proportional to their magnetization at $0.47 \mathrm{~T}(4.7 \mathrm{KOe})$. The NPs showed a fast uptake and no cytotoxicity at concentrations below $62.5 \mu \mathrm{g} / \mathrm{mL}$ with respect to Hela cells. These characteristics define them as potentially useful $T_{2}$ weighed (negative contrast) MRI contrast agents for further biomedical applications.

\section{Experimental Section}

Materials and purification methods: $\mathrm{Fe}\left(\mathrm{NO}_{3}\right)_{3} \cdot 9 \mathrm{H}_{2} \mathrm{O}(>98 \%)$, $\mathrm{Gd}\left(\mathrm{NO}_{3}\right)_{3} \cdot 6 \mathrm{H}_{2} \mathrm{O} \quad(99.99 \%), \quad \mathrm{Eu}\left(\mathrm{NO}_{3}\right)_{3} \cdot 5 \mathrm{H}_{2} \mathrm{O} \quad(99.9 \%)$, $\mathrm{Tb}\left(\mathrm{NO}_{3}\right)_{3} \cdot 5 \mathrm{H}_{2} \mathrm{O}(99.9 \%)$ and nitric acid were purchased from Sigma-Aldrich and used as received. Water was deionized (resistivity larger than $18 \mathrm{MQ}$ ). All the other reagents, of analytical grade, were purchased from Sigma-Aldrich and used without further purification.

Preparation of the nanoparticles: According to the stoichiometric composition reactants, specified amounts of $\mathrm{Fe}$ $\left(\mathrm{NO}_{3}\right)_{3} \cdot 9 \mathrm{H}_{2} \mathrm{O}$ and hydrated $\mathrm{Ln}\left(\mathrm{NO}_{3}\right)_{3}(\mathrm{Ln}=\mathrm{Eu}, \mathrm{Gd}, \mathrm{Tb})$ were first dissolved in nitric acid solution as follows: $1 \mathrm{mmol}$ of of $\mathrm{Fe}$ $\left(\mathrm{NO}_{3}\right)_{3} \cdot 9 \mathrm{H}_{2} \mathrm{O}, 1 \mathrm{mmol}$ of $\mathrm{Eu}\left(\mathrm{NO}_{3}\right)_{3}$ and $1 \mathrm{mmol} \mathrm{HNO}_{3}$. $3 \mathrm{mmol}$ of citric acid were also dissolved into the nitric solution. The sol was heated in a sand bath at $200^{\circ} \mathrm{C}$ in order to evaporate all the solvent and a brown, puffy, porous dry gel was formed. Autocombustion of the formed gel was induced with a flame until the gel burned completely into a loose powder, known as assynthesized powder. The calcination took place according to the following cycle: $1.5 \mathrm{~h}$ increasing sample temperature to $400 \stackrel{\circ}{\circ}$, $2 \mathrm{~h}$ at $400{ }^{\circ} \mathrm{C}$, milling the sample, $1.5 \mathrm{~h}$ temperature increase to $800{ }^{\circ} \mathrm{C}$, mill the sample, and calcine it for $6 \mathrm{~h}$ at $800{ }^{\circ} \mathrm{C}$.

Particle Characterization: The morphologies of the nanoparticles were observed by TEM measurements performed at room temperature on a JEOL JEM-2000 FX transmission electron microscope using an accelerating voltage of $200 \mathrm{kV}$. Drops of diluted water dispersions of nanoparticles were airdried on amorphous carbon films deposited on 200-mesh copper grids. Average particle sizes ( $D_{\text {TEM }}$ ) were calculated by analyzing at least 250 particles randomly selected from TEM micrographs. The iron, europium, terbium, and gadolinium contents were measured by inductively coupled plasma / optical emission spectrometry ICP/OES (ES720, Varian) equipped with a crossflow nebulizer. Solutions for each element with a concentration of $1 \mathrm{~g} / \mathrm{L}$ were used to prepare the standard solutions (SCP Science to Paris) and were used as internal standard to evaluate the instrumental drift.

Diffraction data were obtained on a Philips X'Pert MPD PRO powder diffractometer in the Bragg- Brentano geometry, using Cu- $\mathrm{K}_{\alpha}$ radiation $\left(\mathrm{K}_{\alpha 1}=1.54059 \AA\right.$ and $\mathrm{K}_{\mathrm{a} 2}=1.54441 \AA$, $45 \mathrm{kV}, 40$ $\mathrm{mA})$. The data collections were made in the $6-80^{\circ} 2 \theta$ range with a $0.02^{\circ}$ step. Samples are shown to be single-phase, with peaks indexed to the $D_{2 h}{ }^{16}$ - Pbnm space group (62). The diffraction data were analyzed using the Le Bail whole pattern fitting method, as implemented in the PowderCell software. 
The magnetization of dried nanoparticles was measured using a Quantum Design MPMS-5S SQUID magnetometer. Magnetization values were acquired as a function of applied magnetic field $[M(H)]$ by using about $10 \mathrm{mg}$ of nanopowder per measurement. Hysteresis cycles were measured at $5 \mathrm{~K}$ and 300 $\mathrm{K}$ at a magnetic field range of -50000 Oe to $50000 \mathrm{Oe}$.

${ }^{57} \mathrm{Fe}$ Mössbauer spectra were recorded at $293 \mathrm{~K}$ in a conventional transmission geometry spectrometer using a triangular driving, with a $30 \mathrm{mCi}{ }^{57} \mathrm{Co}$ (Rh matrix) source. The spectra were analysed by using the least squares method assuming Lorentzian line shapes. The isomer shifts values are relative to $\alpha-\mathrm{Fe}$ at $293 \mathrm{~K}$. Powder samples were measured in acrylic holders of $1.5 \mathrm{~mm}$ diameter, covering all the surface area When necessary, the samples were mixed with boron nitride to be able to cover the whole surface.

The zeta potential of the nanoparticles in solution was assessed using a Zetasizer $3000 \mathrm{HSA}$ setup (Malvern Instruments) equipped with a He-Ne laser $(50 \mathrm{~mW}, 532 \mathrm{~nm})$. The zeta potential measurement based on laser Doppler interferometry was used to measure the electrophoretic mobility of the nanoparticles. Measurements were performed for $20 \mathrm{~s}$ using a standard capillary electrophoresis cell. The dielectric constant was set to 80.4 and the Smoluchowsky constant was 1.5.

${ }^{1} \mathrm{H}$ longitudinal and transverse relaxation times $\left(T_{1}\right.$ and $T_{2}$ respectively) of aqueous suspensions of nanoparticles were measured by magnetic resonance relaxometry (Bruker Minispec mq20 relaxometer operating at a magnetic field of $0.47 \mathrm{~T}$, corresponding to a proton Larmor frequency of $20 \mathrm{MHz}$ ). $T_{1}$ values were measured using the inversion recovery pulse sequence, while $T_{2}$ values were measured using a Carr-PurcellMeiboom-Gill (CPMG) pulse sequence. A linear dependence between the inverse proton relaxation times (i.e. the water proton relaxation rates $\left.R_{\mathrm{i}}=1 / T_{\mathrm{i}}, i=1,2\right)$ and the $\mathrm{Ln}^{3+}$ concentration is expected for the magnetic nanomaterials, in accordance with the equation $\left(1 / T_{\mathrm{i}, \text { obs }}\right)=\left(1 / T_{\mathrm{i}, 0}\right)+r_{\mathrm{i}}[\mathrm{Ln}]$, where $T_{\mathrm{i}, \text { obs }}(i=1,2)$ is the relaxation time measured experimentally in the presence of the magnetic nanomaterial, $T_{i, 0}$ is the relaxation time of pure water in the absence of the contrast agent, [M] is the $\mathrm{Ln}^{3+}$ concentration $(\mathrm{mM})$ in the contrast agent and $r_{\mathrm{i}}$ is the longitudinal $(i=1)$ or transverse $(i=2)$ relaxivity (i.e. proton relaxation rate enhancement per $\mathrm{mM} \mathrm{Ln}^{3+}$ ). All the experimental values were corrected for the diamagnetic aqueous contributions under the same conditions.

The quantification of the free $\operatorname{Ln}^{3+}(\mathrm{Ln}=\mathrm{Eu}, \mathrm{Gd}, \mathrm{Tb})$ ions leached from the NPs was carried out using the spectrophotometric method based on the differences in the visible spectra of free and complexed xylenol orange dye, as described in the literature. ${ }^{[1]}$ Briefly, $3.43 \mathrm{~g}$ of xylenol orange were dissolved in $250 \mathrm{~mL}$ buffer solution (acetic acid and $\mathrm{NaOH}$, $\mathrm{pH}=5.81$ ) and the solution was stored at $4 \stackrel{\circ}{\circ} \mathrm{C}$ for one week. An aqueous dispersion of the $\mathrm{LnFeO}_{3} \mathrm{NPs}\left(\mathrm{EuFeO}_{3}: 0.77 \mathrm{mM}\right.$, $\mathrm{GdFeO}_{3}: 1.35 \mathrm{mM}$ and $\mathrm{EuFeO}_{3}: 1.32 \mathrm{mM}$ ) in the buffer xylenol orange solution was also stored at $4^{\circ} \mathrm{C}$ for a week. Calibration curves were built with free $\mathrm{Gd}^{3+}$ ions in solutions $(0-70 \mu \mathrm{M})$, prepared with the buffer solution and dissolving $\mathrm{LnFeO}_{3}$ with nitric acid $\left(\mathrm{HNO}_{3}\right)$. The calibration curve was determined from the plot of the ratio between the integrated intensities of the UVvisible absorption bands at 563 and $446 \mathrm{~nm}$ vs. the $\mathrm{Ln}^{3+}$ concentration (Fig S5A). Finally, the absorption spectrum of an aqueous dispersion of $\mathrm{LnFeO}_{3}$ in the buffer solution was recorded under the same experimental conditions used for the calibration curve data and the amount of free $\mathrm{Ln}^{3+}$ was estimated from the curve (Fig. S5B). $2 \mathrm{mM}$ aqueous suspensions of the NPs, stored at $4 \stackrel{\circ}{\circ}$ for a week, were incubated in $1.5 \mathrm{~mL}$ of 20 $\mathrm{mM}$ xylenol orange solution $(\mathrm{pH} 7.4)$ to allow free $\mathrm{Ln}^{3+}$ ions to form a complex with the arsenazo ligand. The resultant suspension was filtered through a $0.45 \mu \mathrm{m}$ filter. The filtrate was then analysed at $0.5 \mathrm{~nm}$ on a Jasco V-560 UV/VIS spectrophotometer. Quartz cells (10 $\mathrm{mm}$ path length) were used. Water and a $0.076 \mathrm{mM} \mathrm{GdCl}_{3}$ solution were used as negative and positive controls respectively.

Cell internalization and cytotoxicity of NPs: Hela cells were grown in Dulbecco's modified Eagle's medium (DMEM) supplemented with $10 \%(\mathrm{v} / \mathrm{v})$ fetal bovine serum (FBS), 10 $\mathrm{U} / \mathrm{mL}$ penicillin, and $10 \mu \mathrm{g} / \mathrm{mL}$ streptomycin at $37{ }^{\circ} \mathrm{C}$ in fully humidified air containing $5 \% \mathrm{CO}_{2}$. The cells were fed every 2-3 d. The cells were passaged after reaching $80 \%$ confluency. Cells $\left(5 \times 10^{5}\right.$ cells/well) were plated in six-well plates and left to adhere overnight. Then, the cells were incubated with $\mathrm{EuFeO}_{3}$, $\mathrm{TbFeO}_{3}$ and $\mathrm{GdFeO}_{3}(50 \mu \mathrm{g} / \mathrm{mL})$ for 2, 4 and 6 h. After incubation, to remove non-internalized NPs, the cells were washed three times with phosphate-buffered saline (PBS), dissociated with trypsin $[0.2 \%(\mathrm{w} / \mathrm{v})$ in PBS], centrifuged and counted. Afterwards, the samples were freeze-dried, and the presence of $\mathrm{Fe}, \mathrm{Gd}$ and $\mathrm{Eu}, \mathrm{Tb}$ in the samples was evaluated by ICP-MS (ICP/OES (ES720, Varian) equipped with a crossflow nebulizer). For this purpose, the samples were digested overnight in the presence of nitric acid $[0.5 \mathrm{~mL}, 68 \%$, (w/v)], and hydrofluoric acid $[0.5 \mathrm{~mL}, 48 \%(\mathrm{w} / \mathrm{v})]$. Dilution of the sample was performed by addition of $1 \mathrm{~mL}$ of $\mathrm{ddH}_{2} \mathrm{O}$. The samples $(\mathrm{n}=3)$ were analyzed by ICP-MS to quantify internalized elements ( $\mathrm{Fe}$, $\mathrm{Eu}, \mathrm{Tb}$ and $\mathrm{Gd}) .{ }^{[94]}$

Cell toxicity was evaluated by the effect of NPs on ATP production. Hela cells $\left(7 \times 10^{3}\right.$ cells/well) were seeded onto a 96 well plate and left to adhere. The cells were then incubated for 4h with NPs with different concentrations $(7.8125,15.625,31.25$, $62.5,125,250 \mu \mathrm{g} / \mathrm{mL})$. After incubation, to remove noninternalized NPs, the cells were washed three times with phosphate-buffered saline (PBS). After 24h, ATP production was measured by a Celltiter-Glo Luminescent Cell Viability Assay (Promega) on a Synergy H1 Multi-Mode Reader (BioTek Instruments).

Supporting Information (see footnote on the first page of this article): Figures1. Size distributions of the a) $\mathrm{EuFeO}_{3}$ and b) $\mathrm{TbFeO}_{3} \mathrm{NPs}$ estimated on a minimum of 100 measurements.

Figure S2. Zeta potential titrations as a function of $\mathrm{pH}$ for $\mathrm{GdFeO}_{3}(\bullet), \mathrm{EuFeO}_{3}(\bullet)$ and $\mathrm{TbFeO}_{3}(\bullet) \mathrm{NPs}$ in aqueous solution.

Figure S3. Plots of relaxation rates $R_{1}\left(1 / T_{1}\right)$ as a function of $\mathrm{LnFeO}_{3}$ concentration $20 \mathrm{MHz}$ at a) $298 \mathrm{~K}$ and b) $310 \mathrm{~K}$ the corresponding linear regressions. I- $\mathrm{Gd}^{3+}$; II- $\mathrm{Eu}^{3+}$ and III- $\mathrm{Tb}^{3+}$.); Figure S4. Plots of relaxation rates $R_{2}\left(1 / T_{2}\right)$ as a function of $\mathrm{LnFeO}_{3}$ concentration $20 \mathrm{MHz}$ at a) $298 \mathrm{~K}$ and b) $310 \mathrm{~K}$ the corresponding linear regressions. I- $\mathrm{Gd}^{3+} ; \mathrm{II}-\mathrm{Eu}^{3+}$ and $\mathrm{III}-\mathrm{Tb}^{3+}$. Figure S5. A) Spectrophotometric determination of free $\mathrm{Ln}^{3+}$ complexed by xylenol orange. The increase in $\mathrm{Gd}^{3+}$ concentration causes a decrease of the band intensity at $433 \mathrm{~nm}$ and a corresponding increase of the band a $t 563 \mathrm{~nm}$. The spectra were recorded in acetic buffer solution at $\mathrm{pH} 5.8$ in the presence of $0,1,6,10,16,26,30,36,40,60$ and $70 \square \mathrm{M}$ of $\mathrm{Gd}^{3+}$, respectively. B) Calibration curve obtained by spectrophotometric changes of xylenol Orange absorptions in 
the presence of different amounts of $\mathrm{Ln}^{3+}$, and free $\mathrm{Ln}^{3+}$ from the respective $\mathrm{EuFeO}_{3}, \mathrm{GdFeO}_{3}$, and $\mathrm{TbFeO}_{3} \mathrm{NPs}$.

\section{Acknowledgements}

This work was supported by the Fundação para a Ciência e Tecnologia (FCT), Portugal (grants to SLCP (SFRH / BPD / 96048 / 2013), and project PTDC/CTM/73243/2006), the CNRS, the Région Aquitaine France, FEDER, COST Action D38 "MetalBased systems for Molecular Imaging Applications". This work was developed within the scope of the project CICECO-Aveiro Institute of Materials, POCI-01-0145-FEDER-007679 (FCT Ref. UID /CTM /50011/2013), financed by national funds through the FCT/MEC and when appropriate co-financed by FEDER under the PT2020 Partnership Agreement. JSA acknowledges FCT IF/01089/2015 grant.

Keywords: Nanocrystals / Lanthanides/ Orthoferrites/ Relaxivity / MRI contrast agents

[1] P. Caravan, J. J. Ellison, T. J. McMurry, R. B. Lauffer, Chem. Rev. (Washington, D. C.) 1999, 99, 2293-2352.

[2] A Merbach, L. Helm, E. Toth, Editors, The Chemistry of Contrast Agents in Medical Magnetic Resonance Imaging, John Wiley \& Sons Ltd., 2013.

[3] C. F. G. C. Geraldes, S. Laurent, Contrast Media Mol. Imaging 2009, 4, 1-23.

[4] S. Laurent, J.-L. Bridot, L. Vander Elst, R. N. Muller, Future Med. Chem. 2010, 2, 427-449.

[5] S. Laurent, D. Forge, M. Port, A. Roch, C. Robic, L. Vander Elst, R. N. Muller, Chem. Rev. (Washington, DC, U. S.) 2008, 108, 2064 2110.

[6] S. L. C. Pinho, H. Faneca, C. F. G. C. Geraldes, M.-H. Delville, L. D. Carlos, J. Rocha, Biomaterials 2012, 33, 925-935. S. L. C. Pinho, H. Faneca, C. F. G. C. Geraldes, J. Rocha, L. D. Carlos, M.-H. Delville, Eur. J. Inorg. Chem. 2012, 2012, 2828-2837. S. L. C. Pinho, S. Laurent, J. Rocha, A. Roch, M.-H. Delville, S. Mornet, L. D. Carlos, L. Vander Elst, R. N. Muller, C. F. G. C. Geraldes, J. Phys. Chem. C 2012, 116, 2285-2291.

[9] S. L. C. Pinho, G. A. Pereira, P. Voisin, J. Kassem, V. Bouchaud, L. Etienne, J. A. Peters, L. D. Carlos, S. Mornet, C. F. G. C. Geraldes, J. Rocha, M.-H. Delville, ACS Nano 2010, 4, 5339-5349.

[10] R. Xing, G. Liu, J. Zhu, Y. Hou, X. Chen, Pharmaceutical Research 2014, 31, 1377-1389.

[11] S. Roux, O. Tillement, C. Billotey, J.-L. Coll, G. Le Duc, C. A Marquette, P. Perriat, Int. J. Nanotechnol. 2010, 7, 781-801.

[12] J.-L. Bridot, A.-C. Faure, S. Laurent, C. Riviere, C. Billotey, B. Hiba, M. Janier, V. Josserand, J.-L. Coll, L. Vander Elst, R. Muller, S. Roux, P. Perriat, O. Tillement, J. Am. Chem. Soc. 2007, 129, 5076-5084.

[13] F. Lux, S. Roux, P. Perriat, O. Tillement, Curr. Inorg. Chem. 2011, $1,117-129$

[14] M.-A. Fortin, R. M. Petoral, Jr., F. Soederlind, A. Klasson, M. Engstroem, T. Veres, P.-O. Kaell, K. Uvdal, Nanotechnology 2007 18, 395501/395501-395501/395509.

[15] J. Cheon, J.-H. Lee, Accounts of Chemical Research 2008, 41 1630-1640. $2008,60,1241-1251$. J. Gao, H. Gu, B. Xu, Accounts of Chemical Research 2009, 42, 1097-1107.

Q. Le Trequesser, G. Devès, G. Saez, L. Daudin, P. Barberet, C. Michelet, M.-H. Delville, H. Seznec, Analytical Chemistry 2014, 86, 7311-7319.

[19] F. Li, D. Zhi, Y. Luo, J. Zhang, X. Nan, Y. Zhang, W. Zhou, B. Quu, L. Wen, G. Liang, Nanoscale 2016, 8, 12826-12833.

[20] M. Yang, L. Gao, K. Liu, C. Luo, Y. Wang, L. Yu, H. Peng, W. Zhang, Talanta 2015, 131, 661-665.

[21] N. A. Keasberry, M. Banobre-Lopez, C. Wood, G. J. Stasiuk, J. Gallo, N. J. Long, Nanoscale 2015, 7, 16119-16128. J.-s. Choi, J.-H. Lee, T.-H. Shin, H.-T. Song, E. Y. Kim, J. Cheon, Journal of the American Chemical Society 2010, 132, 11015 11017.
Z. Zhou, D. Huang, J. Bao, Q. Chen, G. Liu, Z. Chen, X. Chen, J. Gao, Advanced Materials 2012, 24, 6223-6228.

M. A. Peña, J. L. G. Fierro, Chemical Reviews 2001, 101, 19812018.

V. V. Kharton, A. A. Yaremchenko, A. V. Kovalevsky, A. P. Viskup, E. N. Naumovich, P. F. Kerko, Journal of Membrane Science 1999, 163, 307-317.

D. S. Schmool, N. Keller, M. Guyot, R. Krishnan, M. Tessier, J. Magn. Magn. Mater. 1999, 195, 291-298.

E. Traversa, S. Matsushima, G. Okada, Y. Sadaoka, Y. Sakai, K. Watanabe, Sensors and Actuators B: Chemical 1995, 25, 661-664. N. Keller, J. Mistrik, S. Visnovsky, D. S. Schmool, Y. Dumont, P. Renaudin, M. Guyot, R. Krishnan, Eur. Phys. J. B 2001, 21, 67-73. N. Kojima, K. Tsushima, Low Temp. Phys. 2002, 28, 480-490. S. V. Chavan, A. K. Tyagi, J. Mater. Res. 2005, 20, 2654-2659. M. Sivakumar, A. Gedanken, D. Bhattacharya, I. Brukental, Y. Yeshurun, W. Zhong, Y. W. Du, I. Felner, I. Nowik, Chem. Mater. 2004, 16, 3623-3632.

S. Mathur, H. Shen, N. Lecerf, A. Kjekshus, H. Fjellvåg, G. F. Goya, Advanced Materials 2002, 14, 1405-1409.

J.-H. Lee, Y. K. Jeong, J. H. Park, M.-A. Oak, H. M. Jang, J. Y Son, J. F. Scott, Physical Review Letters 2011, 107, 117201. Y. K. Jeong, J.-H. Lee, S.-J. Ahn, S.-W. Song, H. M. Jang, H. Choi, J. F. Scott, Journal of the American Chemical Society 2012, 134 1450-1453.

S. Cao, L. Chen, W. Zhao, K. Xu, G. Wang, Y. Yang, B. Kang, H. Zhao, P. Chen, A. Stroppa, R.-K. Zheng, J. Zhang, W. Ren, J. Íñiguez, L. Bellaiche, Scientific Reports 2016, 6, 37529.

V. M. Goldschmidt, T. Barth, G. Lunde, W. Zachariasen, Skrifter Norske Videnskaps-Akad. Oslo, Mat.-Nat. KI. 1926, No. 2, 117 pp. S. Geller, Acta Crystallogr. 1956, 9, 885-889.

S. Geller, E. A. Wood, Acta Crystallogr. 1956, 9, 563-568.

Y. Sadaoka, K. Watanabe, Y. Sakai, M. Sakamoto, J. Alloys Compd. 1995, 224, 194-198.

N. Kondo, H. Itoh, M. Kurihara, M. Sakamoto, H. Aono, Y. Sadaoka, Journal of Alloys and Compounds 2006, 408-412, 10261029.

C. Vázquez-Vázquez, P. Kögerler, M. A. López-Quintela, R. D. Sánchez, J. Rivas, Journal of Materials Research 1998, 13, 451. 456.

X. Niu, W. Du, W. Du, Sensors and Actuators B: Chemical 2004, 99, 399-404.

F. Soederlind, M. A. Fortin, R. M. Petoral, Jr., A. Klasson, T. Veres, M. Engstroem, K. Uvdal, P.-O. Kaell, Nanotechnology 2008, 19, 085608/085601-085608/085608.

X. Qi, J. Zhou, Z. Yue, Z. Gui, L. Li, Ceramics International 2003 , 29, 347-349.

S. Farhadi, Z. Momeni, M. Taherimehr, Journal of Alloys and Compounds 2009, 471, L5-L8.

S. S. Manoharan, K. C. Patil, Journal of Solid State Chemistry 1993, 102, 267-276.

H.-B. Park, H.-J. Kweon, Y.-S. Hong, S.-J. Kim, K. Kim, Journal of Materials Science 1997, 32, 57-65.

Z. Yue, J. Zhou, L. Li, H. Zhang, Z. Gui, Journal of Magnetism and Magnetic Materials 2000, 208, 55-60.

K. D. Martinson, I. S. Kondrashkova, V. I. Popkov, Russian Journal Of Applied Chemistry 2017, 90, 1214-1218.

H. Xu, X. Hu, L. Zhang, Crystal Growth \& Design 2008, 8, 20612065.

S. Hosokawa, H.-J. Jeon, S. Iwamoto, M. Inoue, Journal of the American Ceramic Society 2009, 92, 2847-2853.

W. Zheng, R. Liu, D. Peng, G. Meng, Materials Letters 2000, 43, 19-22.

M. Marezio, J. P. Remeika, P. D. Dernier, Acta Crystallographica Section B 1970, 26, 2008-2022.

Z. Zhou, L. Guo, H. Yang, Q. Liu, F. Ye, Journal of Alloys and Compounds 2014, 583, 21-31.

R. D. Shannon, Acta Crystallogr., Sect. A 1976, A32, 751-767. M. Ristic, S. Popović, S. Musić, J Mater Sci Lett 1990, 9, 872-875. X. Liu, M. Jin, M. Liu, Hyperfine Interact 1992, 68, 241-244. X. Liu, M. Jin, C. Zhang, Journal of Applied Physics 1992, 71, 5111-5114.

R. Zboril, M. Mashlan, D. Petridis, Chemistry of Materials 2002, 14, 969-982.

S. M. Aliev, I. K. Kamilov, M. M. Guseinov, S. O. Shakhshaev, A. K. Abduev, Russ. Phys. J. 2004, 47, 189-193.

S. B. Kim, S. J. Moon, S. J. Kim, C. S. Kim, Journal of Magnetism and Magnetic Materials 2007, 310, e592-e594.

L. J. Downie, R. J. Goff, W. Kockelmann, S. D. Forder, J. E. Parker, F. D. Morrison, P. Lightfoot, Journal of Solid State Chemistry 2012, 190, 52-60.

M. Florea, M. Alifanti, V. Kuncser, V. I. Parvulescu, Catalysis Today 2013, 208, 56-59.

H. Yang, J. X. Zhang, G. J. Lin, T. Xian, J. L. Jiang, Adv. Powder Technol. 2013, 24, 242-245. 
S. M. Aliev, I. K. Kamilov, M. S. Aliev, Z. G. Ibaev, Phys. Solid State 2014, 56, 1114-1117.

[66] M. Florea, M. Alifanti, V. Kuncser, D. Macovei, N. Apostol, P. Granger, V. I. Parvulescu, J Catal 2014, 316, 130-140.

[67] O. Opuchovic, A. Kareiva, K. Mazeika, D. Baltrunas, J. Magn Magn. Mater. 2017, 422, 425-433.

[68] M. Eibschütz, S. Shtrikman, D. Treves, Physical Review 1967, 156 562-577.

[69] D. Treves, Journal of Applied Physics 1965, 36, 1033-1039.

[70] O. Nikolov, I. Hall, S. N. Barilo, A. A. Mukhin, J. Magn. Magn. Mater. 1996, 152, 75-85

[71] E. F. Bertaut, J. Chappert, J. Mareschal, J. P. Rebouillat, J. Sivardière, Solid State Communications 1967, 5, 293-298.

[72] J. Mareschal, J. Sivardiere, G. F. De Vries, E. F. Bertaut, J. Appl. Phys. 1968, 39, 1364-1366.

[73] A. Apostolov, J. Sivardiere, C. R. Acad. Sci., Paris, Ser. A B 1968 267B, 1315-1318.

[74] R. M. Bozorth, H. J. Williams, D. E. Walsh, Phys. Rev. 1956, 103 572-578.

[75] R. M. Bozorth, Phys. Rev. Lett. 1958, 1, 362-363.

[76] R. M. Bozorth, V. Kramer, J. P. Remeika, Phys. Rev. Lett. 1958, 1 R. M. Bozorth, V. Kramer, J. P. Remeika, Phys. Rev. Lett. 1958,
3-4.

M. Robbins, R. D. Pierce, R. Wolfe, J. Phys. Chem. Solids 1971 32, 1789-1796.

[78] M. Norek, J. A. Peters, Prog. Nucl. Magn. Reson. Spectrosc. 2011 $59,64-82$

[79] N. Luo, X. Tian, J. Xiao, W. Hu, C. Yang, L. Li, D. Chen, J. Appl. Phys. (Melville, NY, U. S.) 2013, 113, 164306/164301164306/164306.

[80]

Y. Gossuin, A. Hocq, Q. L. Vuong, S. Disch, R. P. Hermann, P. Gillis, Nanotechnology 2008, 19, 475102/475101-475102/475108.

[81]
G. Goglio, G. Kaur, S. L. C. Pinho, N. Penin, A. Blandino, C. F. G. C. Geraldes, A. Garcia, M.-H. Delville, Eur. J. Inorg. Chem. 2015 , 1243-1253.

L. Zhou, Z. Gu, X. Liu, W. Yin, G. Tian, L. Yan, S. Jin, W. Ren, G. Xing, W. Li, X. Chang, Z. Hu, Y. Zhao, Journal of Materials Chemistry 2012, 22, 966-974.

J. Y. Park, K. Kattel, W. Xu, H. G. Kim, E. J. Lee, G. H. Lee, J. J. Lee, Y. Chang, T. J. Kim, J. Korean Phys. Soc. 2011, 59, 23762380.

Z. Hu, M. Ahren, L. Selegard, C. Skoglund, F. Soederlind, M. Engstroem, X. Zhang, K. Uvdal, Chem. - Eur. J. 2013, 19, 1265812667.

N. Luo, X. Tian, C. Yang, J. Xiao, W. Hu, D. Chen, L. Li, Physical Chemistry Chemical Physics 2013, 15, 12235-12240.

D. Vandormael, F. Grandjean, D. Hautot, G. J. Long, J. Phys. Condens. Matter 2001, 13, 1759-1772.

J. H. Jensen, R. Chandra, Magnetic Resonance in Medicine 2000, 44, 144-156.

P. Gillis, F. Moiny, R. A. Brooks, Magnetic Resonance in Medicine 2002, 47, 257-263.

A. Roch, Y. Gossuin, R. N. Muller, P. Gillis, Journal of Magnetism and Magnetic Materials 2005, 293, 532-539.

A. Barge, G. Cravotto, E. Gianolio, F. Fedeli, Contrast Media \& Molecular Imaging 2006, 1, 184-188.

S. P. M. Crouch, R. Kozlowski, K. J. Slater, J. Fletcher, Journal of Immunological Methods 1993, 160, 81-88.

M. A. Malvindi, V. De Matteis, A. Galeone, V. Brunetti, G. C Anyfantis, A. Athanassiou, R. Cingolani, P. P. Pompa, PLoS One 2014, 9, e85835/85831-e85835/85811, 85811 pp.

A. M. Alkilany, P. K. Nagaria, C. R. Hexel, T. J. Shaw, C. J. Murphy, M. D. Wyatt, Small 2009, 5, 701-708. 
Entry for the Table of Contents (Please choose one layout)

Layout 1:

\section{FULL PAPER}

Synthesis and characterization of rare earth orthoferrite $\mathrm{LnFeO}_{3} \mathrm{NPs}$ for bioimaging
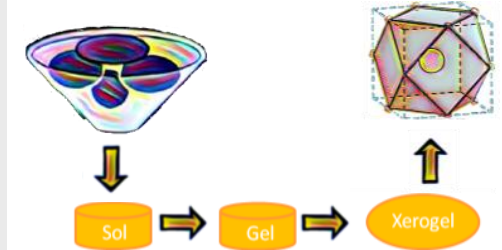

Key Topic* rare earth orthoferrite $\mathrm{LnFeO}_{3}$ nanoparticles as MRI CA.

Sonia L.C. Pinho, João S. Amaral, Alain Wattiaux, Mathieu Duttine, MarieHélène Delville, and Carlos F.G.C. Geraldes*

Page No. - Page No.

*one or two words that highlight the emphasis of the paper or the field of the study 